Article

\title{
The Effect of Managerial Ability on Future Stock Price Crash Risk: Evidence from Korea
}

\author{
Soo Yeon Park ${ }^{1}$ and Hoon Jung ${ }^{2, *}$ \\ 1 Institute for Business Research \& Education, Korea University, Seoul 02841, Korea; sooyeonpark@korea.ac.kr \\ 2 Department of Telecommunications \& Spectrum Research, Korea Information Society Development Institute, \\ Jincheon-gun 27872, Korea \\ * Correspondence: guyhoon@empas.com; Tel.: +82-10-2535-7429
}

Received: 22 October 2017; Accepted: 11 December 2017; Published: 14 December 2017

\begin{abstract}
This study examines the effect of managerial ability on subsequent stock price crash risk using listed firm data in Korea. Compared to some financially advanced countries, the influence of managers is particularly more powerful in Korea, as ownership and management are not effectively separate in most Korean firms. In addition, we considered the effect of large business groups called Chaebol, which is family-run conglomerates with unique corporate governance system that hugely affect the Korean economy. It is important to recognize determinants of the stock price crash risk which would result in doubt on going concern to enhance the company's sustainable management. Hence, this study focuses on the managerial ability as one of the main factors of the stock price crash risk. We use the measures of firm-specific stock price crash risk based on Hutton et al. (2009). Managerial ability is estimated through a Data Envelopment Analysis (DEA) and tobit regressions following Demerjian et al. (2012). From the empirical tests, there is a negative association between managerial ability and stock price crash risk. This suggests that managers with a higher ability release more voluntary disclosure to signal their ability, ultimately lowering the subsequent stock price crash risk. We also find that firms in large business groups, Chaebol, weaken the negative association between managerial ability and subsequent stock price crash risk.
\end{abstract}

Keywords: managerial ability; stock price crash risk; data envelopment analysis; large business groups

\section{Introduction}

This paper aims to analyze the relationship between managerial ability and subsequent stock price crash risk. In addition, this study aims to investigate how such relationships between managerial ability and future stock price crash risk is affected by whether the managers' firm belongs to a large business group.

Managers play a fundamental role in corporate decision-making, and their characteristics are known to affect a wide range of firm strategies from financing, investing, tax reporting [1-3]. Manager-specific factors also impact final decision-making of corporate disclosures, as managers are generally the final decision-makers both on mandatory and voluntary corporate disclosures [4-6]. Moreover, the influence of managers is particularly more powerful in Korea, as ownership and management are not separate in most Korean firms unlike some financially advanced countries where ownership and control are effectively separated.

If the accumulated negative information crosses a certain tipping point, such excessive negative information is flooded into the capital market in the form of bad news, resulting in a stock price crash [7]. The determinants of stock price crash risk have been identified at several levels; Manager-specific, firm-specific, environment-specific levels and so on. Most of the previous studies focused on specific factors at the firm or industry level. Several studies suggest that firm-level evidence such as tax avoidance, discretionary accruals and biased earnings forecast could affect the level of disclosure of 
bad news, which is positively related with subsequent stock price crash risk [8-10]. A firm-specific stock price crash is caused by the accumulation of bad news about the firms. Managers withhold and accumulate bad news mainly because a conflict of interest arises between shareholders and managers, i.e., agency problems, which leads to information asymmetry [11]. In fact, some studies find that one of the causes of stock price crash is agency problems $[7,8,12]$. That is, managers have incentives to delay disclosing negative information about the firms due to an agency problem which exists between shareholders and managers, and thus engage in opportunistic behaviors [11]. Information asymmetry, which is caused by the separation of ownership and control, allows managers to access more inside information [13]. Under such circumstance, if they find negative information, managers withhold and postpone the release of bad news due to their career concerns and reputational risk.

However, these prior studies do not consider manager-specific factors as an independent determinant influencing the release of bad news and subsequent stock price crash risk. Some have overlooked and underestimated how managers' characteristics could have significant implications on the capital market such as stock price crash risk. Before Reference [14] introduced a noble approach called data envelopment analysis (DEA) to measure managerial ability, managerial ability had been difficult to quantify.

To enhance the firm's sustainable management, it is important to identify the determinants of stock price crash risk which would result in a doubt on going concern. Hence, in this study we focus on managerial ability as one of the main factors of stock price crash risks. We view that manager-specific factors would have direct influence on a subsequent stock price crash risk. As such, we focused our attention on managerial ability and conducted an empirical analysis on the relationship between managerial ability and future stock price crash risks; we examined whether higher managerial ability would allow timely disclosure of corporate information, leading to a lower future stock price crash risk, or it would rather motivate managers to hoard bad news out of reputational and career concerns, resulting in a higher future stock price crash risk.

Reference [3] showed that managers' personal background, such as education, work experience and military experience, could affect financial disclosure styles. They explained that individual managers' idiosyncratic characteristics and cognitive biases influence their financial disclosure choices, and corporate outcomes depend on managers' individual attributes. Considering this logic, managerial ability, one of such manager-specific characteristics, could have the following implications on firm's future stock price crash risk.

On the one hand, managerial ability and future stock price crash risk would be negatively related. This is supported by the findings from prior studies, i.e., managers issue voluntary earnings forecasts to signal their ability [15] and managers with higher ability release more voluntary disclosures [16]. On the other hand, CEOs with high ability may be reluctant to disclose management earnings forecasts due to opportunistic reasons $[17,18]$. In this case, managerial ability and future stock price crash risk would be positively related. Given these conflicting views, we can expect that managerial ability would have either positive or negative consequences on firm's future stock price crash risk.

Another important aspect to consider is that the Korean economy has been hugely affected by large business groups called Chaebol, i.e., family-run conglomerates with unique corporate governance systems. People have expressed mixed views on Chaebol. Some say Chaebol have played a leading role in the economic development of Korea in the past years; others argue that itsr closed corporate governance structure where only the majority shareholders have controlling power results in inefficient business management, and minority shareholders suffer loss because the owners selfishly seek personal gains, and its market monopoly hinders balanced growth of the Korean economy. For this reason, it is essential to consider Chaebol's functions, its management behaviors as well as its influence on the Korean economy in an academic research. Despite such importance, not many studies have reached a clear conclusion on this subject. In this respect, this study will also explore whether the managers' firm belongs to a large business group or not has impacts on the relationship between managerial ability and future stock price crash risk. 
In this study, we employed the DEA method suggested by [14] to measure managerial ability, and a market-based measure for stock price crash risk of [7]. We measured managerial ability by estimating firm efficiency by industry group (i.e., firm efficiency of a specific firm is compared to that of its industry peers) and then obtaining residual of the estimated firm efficiency after removal of firm-specific characteristics using the Tobit regression [14]. This assumes managers with a higher level of ability produce higher revenue from a given level of resources and thus provides more precise and direct measures of managerial ability, compared to prior methods in which work experience, education or management performance was used as a proxy for managerial ability.

We conducted our empirical analysis by using 3944 listed firm observations for the period from 2002 to 2014 in Korea and discovered the following results. First, there is a significantly negative association between managerial ability and subsequent stock price crash risk. This negative relationship is in line with the view that managers with a higher level of ability provide more voluntary disclosures, which are useful channel to signal their ability; hence, they exhibit a significantly lower level of future stock price crash risk. Second, the negative relationship between managerial ability and stock price crash risk is weakened when the managers' firm belongs to a large business group. It indicates that the large business group firms have lower demand for corporate information to monitor managers, due to their high access to information and direct involvement in management, hence they play a role of reducing the positive effect of managerial ability on decreased stock price crash risk.

This study contributes to earlier literature in many ways. First, to our knowledge, there is no previous study that assessed the association between managerial ability and subsequent stock price crash risk in Korea. We believe that our empirical results would shed light on how managers' ability influences stock price crash risk. Second, we extended the research on the determinants of stock price crash risk by empirically proving that managers with higher ability leads to lower stock price crash risk. This implies that managerial characteristics, especially manager's ability, affect the entire capital market. Third, our study acknowledges the importance of corporate governance by examining the effect of large business group on the association between managerial ability and subsequent stock price crash risk. Fourth, what makes our empirical analysis differentiated from previous research is that managerial ability is measured using a more sophisticated method to discover additional determinants of future stock price crash risk other than managers' demographic traits or firm-specific effects.

The rest of this paper is organized as follows. Section 2 reviews the prior researches and develops our hypotheses. Section 3 provides the sample and research models, and Section 4 explains the empirical results from the model. Finally, Section 5 presents discussions and conclusion.

\section{Background and Hypotheses}

\subsection{Stock Price Crash Risk}

Firm-specific stock price crash refers to a phenomenon in which stock prices plummet due to excessive negative information poured all at once after bad news accumulates within companies [7]. Since a stock price crash could serve as a factor that damages the capital market participants and hinders rational decision-making, investors, government agencies and academics have become interested in various factors causing stock price crash risk. Several previous studies have identified the causes of firm-specific stock price crash as internal factors $[7,19,20]$ and external factors [21,22].

Many previous studies examined internal factors that cause stock price crash. Reference [9] showed that tax avoidance, which is an opportunistic behavior to conceal negative information, is positively correlated with stock price crash. Reference [19] explored the association between conditional conservatism and firm-level stock price crash. Their empirical analysis showed that the greater the degree of conservatism, the less the probability of a future share price collapse and such a relationship is stronger in an environment with large information asymmetry as measured by $R \& D$ costs, industrial competitiveness and financial analysts' numbers. One of the important internal factors related to stock price crash is disclosure. Reference [7] examined the relationship between the 
opacity of financial statements and stock price crash risk, by measuring firm opacity with discretionary accruals; their empirical result illustrated that a stock price crash risk increases as uncertainty of financial statements increases. This implies that the opacity of information provided by mandatory disclosure shows a positive relationship with stock price crash risks. The measure of stock price crash risk ins [7] and Reference [23] showed that the greater the financial statement comparability, the lower the likelihood of bad news accumulating within the firm, thereby lowering the likelihood of a stock price crash risk. Reference [10] showed a positive relationship between earnings guidance and stock price crash risk, which suggests that earnings guidance is more opportunistic rather than informative. Using data of 13 emerging market countries, Reference [24] showed that companies with superior disclosure policies have a low risk of stock price crash, suggesting that company's disclosure policy affects stock price crash risk.

There are other studies on internal factors such as the effects of managerial characteristics on the risk of stock price crash. Reference [20] showed that the greater the manager's confidence, the higher the stock price crash risk. These results indicate that overconfident managers tend to overestimate future cash flow from a project, misinterpret investments with negative Net Present Value (NPV) as incremental investments, and ignore negative feedback. Reference [25] examined the relationship between CEO age and stock price crash risks. They showed that firms with younger CEOs are more likely to associate with stock price crashes. This implies that CEOs have incentives to delay bad news earlier in their career, increasing the possibility of future stock price crash.

Some researchers have studied external factors in addition to the factors internal to companies. Reference [12] analyzed the relationship between stock price crash risk and the opacity of the stock market measured by transparency index, accounting standards and the number of accounting auditors from 40 countries. According to their analysis, there is a positive correlation between stock price crash risk and the opacity of the stock market. Reference [21] reported that the role of institutional investors could affect stock price crash. There has been criticism that institutional investors play a monitoring and supervising role, while they behave opportunistically to gain short-term profit; their empirical analysis showed that institutional investors mitigate stock price crash risk by monitoring and supervising corporations. Reference [22], using the Chinese market as an emerging market, showed the more the number of financial analysts and the more optimistic forecasts are reported, the more the stock price crash risk increases. As financial analysts in emerging markets provide more general market information than company-specific information, insufficient firm-specific information can lead to an increase in firm-specific stock price crash.

Meanwhile, there have been few studies that directly analyze the impact of managerial ability on stock price crash risk. Therefore, this study focuses on the role of managerial ability as a determinant influencing stock price crash risk.

\subsection{Managerial Ability}

According to prior studies, the characteristics of managers such as leadership influence not only firm performance but also its management, economic research and business practice are important [26,27]. Prior studies in the accounting field related to CEO characteristics have mainly analyzed managerial style or demographic characteristics of managers. Reference [2] used managerial replacement samples to separate managerial effects from firm characteristics, and showed that managerial style affects research and development, investment and financial decision-making and is also related to firm performance and compensation. Reference [17] examined more directly the impact of manager's reputation, measured by their exposure to the media, on accounting information. They showed a negative relationship between manager's reputation and discretionary accruals. This empirical result implies that manager's reputation positively affects earnings quality.

Recently, Reference [14] presented a new managerial ability measure using accounting information. Previously, managerial ability indicators were developed by measuring the extent to which managers achieve more revenue under limited resources. Reference [14] measured managerial ability by using 
the data envelopment analysis to determine firm efficiency and then the Tobit regression to remove the effects of firm characteristics that affect firm efficiency. In addition, Reference [28] empirically analyzed the relation between managerial ability and earnings quality using DEA measures. The result suggested that the higher managerial ability is, the higher earnings quality becomes. Reference [29] investigated whether there is an incremental effects of managerial ability on tax avoidance using DEA. They showed a negative relationship between tax avoidance and firm value. Also, they found a statistically negative relation between managerial ability and tax avoidance. These results imply that high managerial ability mitigates the negative association between tax avoidance and firm value. Reference [16] showed both the likelihood and frequency of management earnings forecast increases proportional to CEO ability measured by DEA. These results indicate that high-ability managers have incentives to signal their capabilities and issue information about their ability to indicate potential changes to their firms' underlying economics.

\subsection{Large Business Groups}

Large business groups are not only found in Korea but throughout the world [30]. According to the Korea Fair Trade Commission (Sejong, Korea), companies with total assets of at least Korean Won (KRW) five trillion are designated as large business groups. When it comes to large business groups such as Chaebol, there are conflicting views whether they have efficient corporate governance mechanisms. Reference [31] suggested that the control-ownership wedge is positively associated with earnings management, and Reference [32] documented a negative relation between control-ownership wedge and conservative reporting. On the other hand, Reference [33] demonstrated that group affiliation allows firms to effectively allocate internal capital and reduce information asymmetry. In other words, firms of large business group show relatively better management performance.

Many researchers have studied the relation between large business groups and financial reporting. Reference [34] reported a negative relation between the control-ownership wedge and the level of corporate disclosure. This means that firms with a high control-ownership wedge tend to avoid detailed disclosure of corporate information. Reference [35] proved that family firms provide fewer earnings forecasts and conference calls compared to nonfamily firms. A family firm is a firm in which the founder or family members of the founder hold positions in top management, are on the board, or are shareholders of the firm. Such family firms show concentrated ownership, and their long-term shareholders exert a dominant influence on management [36]. Considering the relatively long-term nature of founding-family ownership, owners are more concerned about potential cost implications of voluntary disclosure than its benefits. Also, as owners are more directly engaged in management and have more access to internal information, information asymmetry between shareholders and managers would be reduced in the case of family firms. Given the substitutive relation between monitoring of managers and public disclosure, both of which are potential solutions to agency problems [37], family firm owners demand less information for monitoring of their managers since they are already better positioned to monitor the management. This explains why the owners of family firms do not prefer voluntary disclosure.

However, there have been opposing views that firms belonging to a large business group are proactive in voluntary disclosure. Reference [38] showed that firms in large business groups in Korea have a more active financial reporting policy compared to firms in non-large business group. This means that controlling shareholders of large business group firms are highly interested in reaping the benefit of voluntary disclosure by being proactive in corporate disclosure. The researchers interpreted this as an attempt by large business groups to dissuade their negative political and social image as well as to promote their value in the capital market.

\subsection{Hypotheses Development}

Mandatory and voluntary disclosures provided by management are essential intermediaries to share information with external information users and reduce information asymmetry. In addition, 
providing timely and appropriate corporate information may have a significant effect on investor decision-making and alleviate information asymmetry [15]. Since rational investors consider non-disclosure as bad news and thereby devalue the firms, managers have the incentive to disclosure their information [39-42]. Also, to prevent potential costs such as litigation costs or reputation costs by non-disclosure, managers have the incentives to preempt negative information [43]. In particular, when the manager's ability is considered as an intangible asset that cannot be directly measured, disclosed information provided by managers is a useful medium to indirectly signal manager's ability. Hence, managers with high ability have stronger incentives to disclose more information [16] and ultimately lower the risk of stock price crash. In this case, managerial ability is negatively related to subsequent stock price crash risk, as managers are less likely to postpone reporting bad news.

In contrast, a number of previous studies suggested that voluntary disclosure is associated with opportunistic incentives of managers $[17,18]$ and managers would not disclose information properly due to their own interests. Upon announcement of bad news, managers could suffer a loss of compensation, bonuses, stock options, promotion opportunities or even their jobs, hence there are incentives to delay bad news disclosure to relieve career concerns $[11,44]$. In these cases, therefore, managerial ability and future stock price crash risk have a significantly positive correlation.

In this regard, we used the following null hypothesis to analyze the relationship between managerial ability and subsequent stock price crash risk.

Hypothesis 1 (H1). There is no significant relation between managerial ability and companies' future stock price crash risk.

In Korea, firms belonging to a large business group have more active disclosure policies than those do not belong to a large business group [38]. The larger the firms are, the more financial analysts follow them, leading to better information environment. Therefore, the act of concealing negative information by managers would be easily detected. Also, investors and financial analysts do not like negative unexpected earnings, so firms that hold negative information would get bad reputation from them. Such a decline in reputation could be fatal to the corporate value, therefore firms may have incentives to disclose more information.

Since a decline in reputation could seriously damage corporate value, the controlling shareholders are likely to internalize benefits of disclosure as well as costs of non-disclosure. This implies that owners of large business group firms prefer more public disclosure [35]. Therefore, large business group firms can mitigate information asymmetry and prevent bad news from being withheld, thereby strengthening the negative relationship, i.e., weakening the positive relationship, between managerial ability and subsequent stock price crash risk.

On the other hand, the controlling shareholders of large business group firms have similar characteristics to owners of family business companies [38]. The controlling shareholders of large business group firms may have a direct involvement in corporate management based on centralized ownership and have high access to corporate information, hence the demand for corporate information aimed at monitoring managers would be reduced. In this case, firms in large business group can weaken the negative relationship, i.e., strengthen the positive relationship between managerial ability and stock price crash risk.

Therefore, we established the following null hypothesis to analyze how large business group firms influence the relationship between managerial ability and future stock price crash risk.

Hypothesis 2 (H2). Large business groups have no significant impact on the relation between managerial ability and companies' future stock price crash risk. 


\section{Methodology and Empirical Models}

\subsection{Sampling}

For this study, we collected data from KOSPI listed companies. We used financial data extracted from Kis-Value Library, TS-2000 of Korea Listed Companies Association (Seoul, Korea) and Fn-Guide (Seoul, Korea) to construct our variables. Similar to prior literature, we excluded financial institutions, companies ending financial year in months other than December and companies whose financial statements and other important data are unavailable for consistency of samples. The total sample for the fiscal years of 2002-2014 used for empirical analysis of this study is 3944 firm-years. The sample includes the 2008 financial crisis so there may be confounding effect of the results. Hence, to exclude confounding effect, additionally we separated our sample into two sub-periods, for the fiscal years of 2002-2007 and 2009-2014. We replicated our analyses for sub-period and the regression analyses shows similar results (untabulated). We winsorized all variables at the top and bottom 1 percentile to avoid the influence of outliers. Table 1 shows the distribution of sample by year and industry.

Table 1. Distribution of the Sample.

\begin{tabular}{|c|c|c|c|}
\hline \multicolumn{4}{|c|}{ Panel A Year Distribution of the Sample } \\
\hline Fiscal Year & Number of Firms & $\begin{array}{l}\text { Number of Firms with } \\
\text { Stock Price Crash Risk }\end{array}$ & $\begin{array}{l}\text { Percentage of Stock } \\
\text { Price Crash Risk }\end{array}$ \\
\hline 2002 & 226 & 27 & 0.119 \\
\hline 2003 & 248 & 36 & 0.145 \\
\hline 2004 & 265 & 46 & 0.174 \\
\hline 2005 & 276 & 28 & 0.101 \\
\hline 2006 & 291 & 54 & 0.186 \\
\hline 2007 & 302 & 84 & 0.278 \\
\hline 2008 & 308 & 43 & 0.140 \\
\hline 2009 & 318 & 37 & 0.116 \\
\hline 2010 & 320 & 56 & 0.175 \\
\hline 2011 & 362 & 45 & 0.124 \\
\hline 2012 & 343 & 24 & 0.070 \\
\hline 2013 & 342 & 44 & 0.129 \\
\hline 2014 & 343 & 65 & 0.190 \\
\hline Total & 3944 & 589 & 0.149 \\
\hline \multicolumn{4}{|c|}{ Panel B Industry Distribution of the Sample } \\
\hline & & Number of Firms & $\begin{array}{c}\text { Percentage of } \\
\text { the Sample }\end{array}$ \\
\hline \multicolumn{2}{|c|}{ Manufacture of food products } & 288 & 7.26 \\
\hline \multicolumn{2}{|c|}{ Manufacture of textiles } & 48 & 1.22 \\
\hline \multicolumn{2}{|c|}{ Manufacture of wearing apparel } & 89 & 2.26 \\
\hline \multicolumn{2}{|c|}{ Manufacture of paper and paper products } & 85 & 2.16 \\
\hline \multicolumn{2}{|c|}{ Manufacture of chemicals and chemical products } & 481 & 12.20 \\
\hline \multicolumn{2}{|c|}{ Manufacture of basic pharmaceutical products and pharmaceutical preparations } & 171 & 4.34 \\
\hline \multicolumn{2}{|c|}{ Manufacture of rubber and plastic products } & 119 & 3.02 \\
\hline \multicolumn{2}{|c|}{ Manufacture of other non-metallic mineral products } & 106 & 2.69 \\
\hline \multicolumn{2}{|c|}{ Manufacture of basic metals } & 327 & 8.29 \\
\hline \multicolumn{2}{|c|}{ Manufacture of fabricated metal products, except machinery and equipment } & 55 & 1.39 \\
\hline \multicolumn{2}{|c|}{ Manufacture of computer, electronics, and optical products } & 307 & 7.78 \\
\hline \multicolumn{2}{|c|}{ Manufacture of electrical equipment } & 127 & 3.22 \\
\hline \multicolumn{2}{|c|}{ Manufacture of machinery and equipment } & 186 & 4.72 \\
\hline \multicolumn{2}{|c|}{ Manufacture of motor vehicles, trailers and semi-trailers } & 258 & 6.54 \\
\hline \multicolumn{2}{|c|}{ Manufacture of other transport equipment } & 12 & 0.3 \\
\hline \multicolumn{2}{|c|}{ Manufacture of furniture } & 23 & 0.58 \\
\hline \multicolumn{2}{|c|}{ Electricity, gas, steam and air conditioning supply } & 66 & 1.67 \\
\hline \multicolumn{2}{|c|}{ Construction of buildings } & 206 & 5.22 \\
\hline \multicolumn{2}{|c|}{ Wholesale and retail trade and repair of motor vehicles and motorcycles } & 280 & 7.10 \\
\hline \multicolumn{2}{|c|}{ Wholesale trade, except of motor vehicles and motorcycles } & 100 & 2.54 \\
\hline \multicolumn{2}{|c|}{ Land transport and transport via pipelines } & 99 & 2.51 \\
\hline \multicolumn{2}{|c|}{ Water transport } & 5 & 0.13 \\
\hline \multicolumn{2}{|c|}{ Publishing activities } & 7 & 0.18 \\
\hline Computer progra & d related activities & 53 & 1.34 \\
\hline & & 431 & 10.93 \\
\hline Scien & pment & 15 & 0.38 \\
\hline & & 3944 & 100.00 \\
\hline
\end{tabular}

The industry classification is based on the two-digit classification of the Korea Standard Industry Code. 


\subsection{Measurement of Stock Price Crash Risk and Managerial Ability}

\subsubsection{Stock Price Crash Risk}

To analyze the relationship between managerial ability and stock price crash risk, we employed firm-specific stock price crash risk for each firm-year observation, following the previous literature [7]. Firstly, we assessed firm-specific weekly returns from the following market model regression:

$$
\begin{gathered}
\gamma_{i, t}=\beta_{0}+\beta_{1, t} \gamma_{m, t-2}+\beta_{2, t} \gamma_{m, t-1}+\beta_{3, t} \gamma_{m, t}+\beta_{4, t} \gamma_{m, t+1}+\beta_{5, t} \gamma_{m, t+2}+\beta_{6, t} \gamma_{k, t-2} \\
+\beta_{7, t} \gamma_{k, t-1}+\beta_{8, t} \gamma_{k, t+1}+\beta_{9, t} \gamma_{k, t+2}+\epsilon_{i, t}
\end{gathered}
$$

where $\gamma_{i, t}$ is the return on stock $i$ in week $t, \gamma_{m, t}$ is the KOSPI value-weighted market index in week $t$, and $\gamma_{k, t}$ is the return on the value-weighted industry index based on two-digit the Korean Standard Industrial Classification (KSIC) codes. We defined the firm-specific weekly return for firm $i$ in week $t\left(W_{i, t}\right)$ as the natural logarithm of one plus the residual in Equation (1), that is, $W_{i, t}=\ln \left(1+\varepsilon_{i, t}\right)$. We define stock crash weeks in a given fiscal year for a given firm as those weeks during which the firm experiences firm-specific weekly returns 3.09 standard deviations below the mean firm-specific weekly returns over the entire fiscal year. The measure of crash likelihood for each firm in each year, denoted by $C R A S H$, is an indicator variable that equals one for a firm-year that experiences one or more crash weeks (as denoted above) during the fiscal-year period, and zero otherwise. Panel A in Table 1 shows that on average, $14.9 \%$ of firms in ours ample experienced at least one crash event during a given year.

\subsubsection{Managerial Ability}

To measure managerial ability, we employed DEA model suggested by [14]. They supposed that generally high-ability managers produce more sales with limited resources or consume less resource to produce same output (sales). According to [14], managerial ability can be measured by two phases. In the first phase, we calculated the efficient frontier of firms within the same industry by taking into account their sales and combination of input factors. We measured the efficiency score of each firm-year observation using DEA. A firm's efficiency score is one if it is on the efficient frontier; if a firm is further away from the efficient frontier, then it has efficient score lower than one. Maximum efficiency score is one and minimum efficiency score is zero. Following [45], we measured the relative efficiency of firms in the same industry and the same year.

The firm efficiency measurement model by DEA is as below:

$$
\max _{v} \theta=\frac{S A L E S}{v_{1} C O G S+v_{2} S G N A+v_{3} P P E+v_{4} I N T A N}
$$

where,

$$
\begin{aligned}
& \text { SALES = operating revenue } \\
& \text { COGS = cost of goods sold } \\
& \text { SGNA = sales and general administrative expenses } \\
& \text { PPE = tangible assets (tangible assets-land-tree-construction in progress-assets in transit) } \\
& \text { INTAN = intangible assets }
\end{aligned}
$$

The efficiency score of DEA has a limitation. The limitation is the influence of firm-specific factors such as Stock Return (RET) and Return On Asset (ROA). For example, a manager of a large company with middle level ability can have bigger bargaining power in negotiations with suppliers compared to a high-ability manager in a small company. Thus, to remove firm-specific factors related to managerial ability, Reference [14], used the Tobit regression. To put it another way, after removing firm-specific factors from the total efficiency of firm, managerial ability is defined as the unexplained part of the total firm efficiency. To extract the efficiency which is attributed to managers, we performed the Tobit regression analysis including year fixed effects. Lastly, we get the residuals of the Tobit regression. 
Managerial ability could also affect variables attributed to the firm. We used the residual as proxy for managerial ability, given that it is obtained by controlling firm-specific characteristics and therefore means how managers attribute to firm efficiency [14].

The managerial ability measurement model by tobit regression is as below:

$$
\begin{gathered}
\text { FIRMEFFICIENCY } Y_{t}=\beta_{0}+\beta_{1} \text { SIZE }_{t}+\beta_{2} M S_{t}+\beta_{3} F C F_{t} \\
+\beta_{4} A G E+\beta_{5} \text { BUSEG }_{t}+\beta_{6} F C I_{t}+\sum_{t=1}^{T} \varphi_{t} Y E A R_{t}+\eta
\end{gathered}
$$

where,

FIRMEFFICIENCY $=$ the firm efficiency measured by DEA

SIZE $=$ natural log of total assets

$M S$ = firm revenue/total industry revenue

$F C F=1$ if free cash flow (net income before depreciation - change in operating capital - capital expenditure) $>0$, otherwise 0 .

$A G E=$ natural log of (the number of years the firm has been listed +1 )

$B U S E G=$ the number of business departments

$F C I=$ the absolute magnitude of foreign currency translation accounts (foreign currency gain, foreign currency translation loss, gain on foreign currency transactions, loss on foreign currency transactions)/total revenue

Since Reference [14] suggested the measure of managerial ability, the research on managerial ability has been extensively performed $[16,28,45]$. Reference [16] presented that as managerial ability increases, the tendency and frequency of management earnings forecasts increase as well. Reference [16] showed that high-ability managers estimate earnings more accurately compared to low-ability managers, which in turn secures that the market responds more sensitively to the earnings forecasts of such high-ability manager firms compared to low-ability manger firms. Reference [28] presented that high-ability managers mitigate the negative effects of earnings management. Reference [45] showed empirical evidence on the positive association of managerial ability and firm performance using the Korean firm data. Reference [45] also used the same method of [14].

\subsection{Empirical Model}

To examine how managerial ability is associated with firm-specific future stock price crush risk, we estimated the following empirical model which is the research model of $[9,19]$. We used the logit regressions to investigate Hypothesis 1 and Hypothesis 2. We set the empirical models by using the variables of stock crash risk and managerial ability to examine Hypothesis 1 as follows.

$$
\left.\mathrm{CRASH}_{i, t+1}=\alpha_{0}+\alpha_{1} * M A_{i, t}+\sum_{q=2}^{m} \alpha_{p}(q \text { th ControlVariable })_{t}\right)+\epsilon_{t}
$$

According to [16], high-ability managers tend to disclosure more information. More information can alleviate information asymmetry. In this regard, we can expect a negative correlation between managerial ability and stock crash risk. Accordingly, we could predict $\alpha_{1}$ to have a statistically significant negative value. However, some other previous studies showed that voluntary disclosures are associated with opportunistic incentives of managers $[17,18]$. Due to disclosure of bad news, managers could suffer loss of compensation, decrease of bonus and stock option value, promotion opportunities and dismissal, so they are bound to pay attention to their own reputation and tenure. There is also an incentive to delay negative information [11,44]. From the above research, we can predict a positive correlation between managerial ability and stock crash risk, and expect $\alpha_{1}$ to have a statistically significant positive value. If Hypothesis 1 (H1) is supported, the relation between managerial ability and stock crash risk would not be statistically significant. 
The set of control variables include SIZE,$M B_{t}$, TRADING $_{t}$, STDRET $_{t}, M_{N R E T_{t}}, L E V_{t}, B$ STA $_{t}$, $R O A_{t}, O P A Q U E_{t}, T E N U R E_{t}, C R A S H_{t}, Y E A R$ and IND. MB $B_{t}$ is defined as the market-to-book ratio at the end of fiscal year $t$. References $[35,46]$ presented that glamour stocks, i.e., those with low ratios of book value to market value, are more likely to experience future stock price crash. $L E V_{t}$ is defined as the book value of total liabilities divided by the total assets at the end of fiscal year $t$. $R O A_{t}$ is defined as income before extraordinary items divided by the total assets at the end of fiscal year $t$. Reference [7] found that financial leverage and operating performance are both negatively related to stock crash

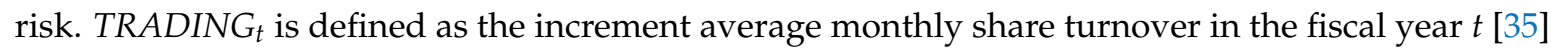
used TRADING $t$ to proxy for the intensity of disagreement among investors, and found that firms that experience larger increase in turnover relative to the trend are more likely to suffer future stock price crash. Following [7], we included a measure of financial reporting opaqueness. OPAQUE $E_{t}$ is the 3-year moving sum of the absolute value of annual performance-adjusted discretionary accruals from fiscal year $t-2$. Reference [7] showed that opaque firms are more likely to experience future stock price crash. TENURE $E_{t}$ is defined the period after the change of CEO. Because of the lack of knowledge and experience [47], uncertainty concerning the ability of short-tenured CEOs to lead the firm creates pressure for such CEOs, for instance by hiding bad news. The definitions and estimation methods of each variable are presented in Table 2.

Hypothesis 2 aims to investigate whether the large business group factor weakens or strengthens the correlation between managerial ability and subsequent stock price crash risk. Based on the above model (4), we set the following model (5) to test Hypothesis 2.

$$
\begin{gathered}
C R A S H_{i, t+1}=\beta_{0}+\beta_{1} M A_{i, t}+\beta_{2} \text { CONGLO }_{i, t}+\beta_{3} M A_{i, t} \\
* \text { CONGLO }_{i, t} \sum_{q=2}^{m} \alpha_{p}(q \text { th Controlvariable } \\
)+\epsilon_{t}
\end{gathered}
$$

\begin{tabular}{|c|c|c|}
\hline & Variables & Descriptions \\
\hline & $\begin{array}{l}\mathrm{CRASH}_{t+1} \\
\mathrm{MA}_{t} \\
\mathrm{CONGLO}_{t}\end{array}$ & $\begin{array}{l}\text { Equals } 1 \text { if a firm experiences one or more crash events in year } t+1 \text {, and zero otherwise; } \\
\text { Managerial ability calculated in year } t \text { by [14]; } \\
\text { Company designated as a large business group by FTC in year } t\end{array}$ \\
\hline Control Variables & $\begin{array}{l}\text { SIZE } \\
\text { MB } \\
\text { TRADING } \\
\text { STDRET }_{t} \\
\text { MNRET }_{t} \\
\text { LEV }_{t} \\
\text { BETA } \\
\text { ROA } \\
\text { OPAQUE } \\
\text { OENURE }\end{array}$ & $\begin{array}{l}\text { Natural log of sales in year } t ; \\
\text { Market value divided by total equity in year } t \\
\text { Increment in monthly turnover rate year on year in year } t \\
\text { Standard deviation of firm-specific weekly returns in year } t \\
\text { Arithmetic average of firm-specific weekly returns in year } t \\
\text { Total debt divided by total assets in year } t ; \\
\text { Beta index of market model during the previous } 60 \text { months; } \\
\text { Operating income divided by total asset in year } t ; \\
\text { 3-year moving sum of the absolute value of annual performance-adjusted discretionary } \\
\text { accruals in year } t \text {; } \\
\text { The period after the change of CEO; }\end{array}$ \\
\hline
\end{tabular}

Table 2. Descriptions of main variables.

\section{Results}

\subsection{Descriptive Statistics and Correlations}

Table 3 presents descriptive statistics for the main variables. The average value of $C R A S H_{t+1}$ is 0.149 , indicating that $14.9 \%$ of firms experience at least one stock price crash event during the years. The mean value of $M A_{t}$ is -0.001 . This value is similar to the estimates found in $[45,48]$. The mean value of $C O N G L O O_{t}$ is 0.244 , showing that the portion of large business group affiliates in the sample is $24.4 \%$, which is comparable to that reported by [38]. The average company size measured by the natural logarithm value of total asset, or $S I Z E_{t}$, is 26.528 and the average of $M B_{t}$, the ratio of market value to book value, which is an indicator of growth rate, is 0.988 . This means that the market value of sample companies is similar to their book value. The average $L E V_{t}$ and $R O A_{t}$ are 0.436 and 0.023 , 
respectively. The average of $O P A Q U E_{t}$, the sum of discretionary accruals over three previous years, is 0.261 .

Table 3. Descriptive statistics for main variables.

\begin{tabular}{cccccc}
\hline Variables & Mean & Std. Dev. & $\mathbf{2 5 \%}$ & Median & $\mathbf{7 5 \%}$ \\
\hline CRASH $_{t+1}$ & 0.149 & 0.356 & 0.000 & 0.000 & 0.000 \\
$M A_{t}$ & -0.001 & 0.091 & -0.047 & -0.003 & 0.041 \\
CONGLO $_{t}$ & 0.244 & 0.429 & 0.000 & 0.000 & 0.000 \\
SIZE $_{t}$ & 26.528 & 1.398 & 25.517 & 26.315 & 27.341 \\
$M B_{t}$ & 0.988 & 0.856 & 0.465 & 0.728 & 1.212 \\
TRADING $_{t}$ & -0.029 & 0.415 & -0.076 & -0.009 & 0.033 \\
STDRET $_{t}$ & 0.055 & 0.023 & 0.040 & 0.050 & 0.065 \\
MNRET $_{t}$ & -0.002 & 0.007 & -0.006 & -0.002 & 0.002 \\
LEV $_{t}$ & 0.436 & 0.197 & 0.288 & 0.442 & 0.580 \\
BETA $_{t}$ & 0.713 & 0.362 & 0.439 & 0.688 & 0.951 \\
ROA $_{t}$ & 0.023 & 0.080 & 0.006 & 0.032 & 0.063 \\
OPAQUE $_{t}$ & 0.261 & 0.593 & 0.065 & 0.111 & 0.183 \\
TENURE $_{t}$ & 5.694 & 4.113 & 2.000 & 5.000 & 8.000 \\
\hline
\end{tabular}

This table reports descriptive statistics of the mean, median, and distributions of main variables used in this paper. All variables are winsorized at the top and bottom one-percentile of the pooled data. Variable definitions are defined in Table 2.

Table 4 shows the Pearson correlation coefficients between the variables of interest. As shown in Table 4, the indicators of managerial ability and subsequent crash risk, $C R A S H_{t+1}$, are highly negatively correlated. Meanwhile, $C O N G L O_{t}$ is not significantly correlated with $C R A S H_{t+1}$. As indicated in previous literature, $C R A S H_{t+1}$ is positively correlated with $L E V$ [7] and negatively correlated with $R O A$ [23]. Managerial ability measures are correlated with SIZE $, S_{t} S_{D R E T}, M N R E T_{t}, L E V_{t}, B E T A_{t}$, $R O A_{t}, O P A Q U E_{t}$, and TENURE . In general, high-ability managers are employed by larger firms. Thus, the correlation between managerial ability measure and $S I Z E_{t}$ shows a significant positive correlation. However, it would be difficult to draw a conclusion on the effect of variables on the relation between managerial ability and future stock price crash risk simply based on this correlation coefficient. Therefore, the final empirical analysis result is reported in the next section considering all variables included in the research model. 
Table 4. Correlations coefficients between variables of interest.

\begin{tabular}{|c|c|c|c|c|c|c|c|c|c|c|c|c|c|c|}
\hline & Variables & (1) & (2) & (3) & (4) & (5) & (6) & (7) & (8) & (9) & (10) & (11) & (12) & (13) \\
\hline (1) & CRASH & 1.000 & & & & & & & & & & & & \\
\hline (2) & $M A$ & $0.074^{* * *}$ & 1.000 & & & & & & & & & & & \\
\hline (3) & CONGLO & -0.004 & 0.017 & 1.000 & & & & & & & & & & \\
\hline (4) & SIZE & -0.027 & $0.053^{* * *}$ & $0.668^{* * *}$ & 1.000 & & & & & & & & & \\
\hline (5) & $M B$ & 0.028 & -0.021 & $0.129^{* * *}$ & $0.123 * * *$ & 1.000 & & & & & & & & \\
\hline (6) & TRADING & 0.026 & -0.006 & 0.022 & $0.044 * *$ & 0.029 & 1.000 & & & & & & & \\
\hline (7) & STDRET & 0.030 & $-0.077^{* * *}$ & $-0.133^{* * *}$ & $-0.282^{* * *}$ & $0.172^{* * *}$ & $0.271^{* * *}$ & 1.000 & & & & & & \\
\hline (8) & MNRET & -0.005 & $0.136^{* * *}$ & $0.032 *$ & $0.098^{* * *}$ & $0.175^{* * *}$ & $0.183^{* * *}$ & $0.105^{* * *}$ & 1.000 & & & & & \\
\hline (9) & LEV & $0.058^{* * *}$ & $-0.069^{* * *}$ & $0.105^{* * *}$ & $0.123^{* * *}$ & $0.125^{* * *}$ & -0.012 & $0.249^{* * *}$ & $-0.059^{* * *}$ & 1.000 & & & & \\
\hline (10) & BETA & -0.026 & $0.058^{* * *}$ & $0.305^{* * *}$ & $0.351^{* * *}$ & $0.137^{* * *}$ & 0.024 & $0.215^{* * *}$ & -0.011 & $0.207^{* * *}$ & 1.000 & & & \\
\hline (11) & $R O A$ & $0.123^{* * *}$ & $0.315^{* * *}$ & $0.076^{* * *}$ & $0.212^{* * *}$ & -0.007 & -0.022 & $-0.304 * * *$ & $0.304^{* * *}$ & $-0.318^{* * *}$ & -0.008 & 1.000 & & \\
\hline (12) & OPAQUE & 0.011 & 0.042 ** & $0.080^{* * *}$ & $0.138^{* * *}$ & 0.012 & 0.015 & $-0.042 * *$ & 0.013 & -0.007 & -0.012 & 0.013 & 1.000 & \\
\hline (13) & TENURE & -0.026 & $0.050 * *$ & $-0.194^{* * *}$ & $-0.063^{* * *}$ & $-0.044^{* *}$ & 0.023 & $-0.121^{* * *}$ & 0.034 * & $-0.158^{* * *}$ & -0.041 * & $0.093^{* * *}$ & $-0.041 *$ & 1.000 \\
\hline
\end{tabular}

This table presents Pearson correlation between the future stock price crash risk variables, the corporate ownership variables, i.e., percentage of managerial ownership and that of foreign ownership, and other control variables. Refer to the Table 2 for variable definitions. ${ }^{* * *}{ }^{* *}$ and ${ }^{*}$ denote the significance level (two-tailed) at $1 \%, 5 \%$ and $10 \%$ or less, respectively. 


\subsection{Regression Analysis Results}

Table 5 Column (1) presents the logistic regression analysis result on the relation between managerial ability and stock crash risk. $M A_{t}$ variable has a negative and significant coefficient, implying that higher-ability managers have lower probabilities of stock price crash risk. The $\mathrm{dF} / \mathrm{dx}$ of $M A$ reports changes in the probability of stock crash when $M A$ changes. The $\mathrm{dF} / \mathrm{dx}$ of $M A$ is -0.141 . When $M A$ increases from -0.017 to 0.001 (the approximate mean difference between stock crash and no stock crash companies), the probability of stock crash risk decreases by $0.26 \%$. This result suggests that managers with higher ability have incentives to preempt negative information to reduce the potential costs relating to nondisclosure, and prefer to disclose more information to signal their ability, ultimately reducing future stock price crash risk. Turning to the control variables, we observed significantly positive coefficients on $M N R E T_{t}$, following [49], implying that higher past mean return increases future crash risk. In addition, consistent with the findings in [50], we found the coefficients on $L E V_{t}$ is positive and significant, indicating that high level of debt holdings increases managerial bad news hoarding, ultimately resulting in higher stock price crash risk. $R O A_{t}$ showed a negative and significant coefficient, similar to [21,50]; this finding is opposite to [7], possibly due to the different sample market.

Table 5. Effect of managerial ability on future stock price crash risk.

\begin{tabular}{|c|c|c|c|c|}
\hline \multirow{2}{*}{ Variables } & \multicolumn{2}{|c|}{ (1) Hypothesis 1} & \multicolumn{2}{|c|}{ (2) Hypothesis 2} \\
\hline & Coefficient & $\mathrm{dF} / \mathrm{dx}$ & Coefficient & $\mathrm{dF} / \mathrm{d} x$ \\
\hline Intercept & $\begin{array}{l}-0.687 \\
(0.593)\end{array}$ & & $\begin{array}{l}-0.595 \\
(0.693)\end{array}$ & \\
\hline$M A_{t}$ & $\begin{array}{c}-1.217^{* *} \\
(0.027)\end{array}$ & $-0.141^{* *}$ & $\begin{array}{c}-1.968^{* * *} \\
(0.002)\end{array}$ & $-0.227^{* * *}$ \\
\hline $\mathrm{CONGLO}_{t}$ & & & $\begin{array}{c}0.030 \\
(0.848)\end{array}$ & 0.003 \\
\hline$M A_{t}^{*} \mathrm{CONGLO} t$ & & & $\begin{array}{c}2.849^{* * *} \\
(0.008)\end{array}$ & $0.328^{* * *}$ \\
\hline$S I Z E_{t}$ & $\begin{array}{l}-0.042 \\
(0.373)\end{array}$ & -0.005 & $\begin{array}{l}-0.046 \\
(0.418)\end{array}$ & -0.005 \\
\hline$M B_{t}$ & $\begin{array}{c}0.026 \\
(0.659)\end{array}$ & 0.003 & $\begin{array}{c}0.019 \\
(0.755)\end{array}$ & 0.002 \\
\hline TRADING ${ }_{t}$ & $\begin{array}{c}0.179 \\
(0.132)\end{array}$ & 0.021 & $\begin{array}{c}0.188 \\
(0.114)\end{array}$ & 0.022 \\
\hline$S T D R E T_{t}$ & $\begin{array}{l}-4.284 \\
(0.140)\end{array}$ & -0.495 & $\begin{array}{l}-4.420 \\
(0.129)\end{array}$ & -0.509 \\
\hline$M N R E T_{t}$ & $\begin{array}{c}15.576^{* *} \\
(0.033)\end{array}$ & $1.801 * *$ & $\begin{array}{c}15.442 * * \\
(0.034)\end{array}$ & $1.779^{* *}$ \\
\hline$L E V_{t}$ & $\begin{array}{l}0.526^{*} \\
(0.065)\end{array}$ & $0.061 *$ & $\begin{array}{l}0.538^{*} \\
(0.060)\end{array}$ & $0.062 *$ \\
\hline$B E T A_{t}$ & $\begin{array}{l}-0.129 \\
(0.434)\end{array}$ & -0.015 & $\begin{array}{l}-0.131 \\
(0.427)\end{array}$ & -0.015 \\
\hline$R O A_{t}$ & $\begin{array}{c}-3.893^{* * *} \\
(0.000)\end{array}$ & $-0.450^{* * *}$ & $\begin{array}{c}-3.781 \text { *** } \\
(0.000)\end{array}$ & $-0.436^{* * *}$ \\
\hline OPAQUE & $\begin{array}{c}0.025 \\
(0.757)\end{array}$ & 0.003 & $\begin{array}{c}0.036 \\
(0.651)\end{array}$ & 0.004 \\
\hline TENURE $_{t}$ & $\begin{array}{c}0.002 \\
(0.879)\end{array}$ & 0.000 & $\begin{array}{c}0.002 \\
(0.870)\end{array}$ & 0.000 \\
\hline $\mathrm{CRASH}_{t}$ & $\begin{array}{c}0.066 \\
(0.644)\end{array}$ & 0.008 & $\begin{array}{c}0.055 \\
(0.700)\end{array}$ & 0.006 \\
\hline Industry dummies & & & & \\
\hline Year dummies & & & & \\
\hline Observations & & & & \\
\hline
\end{tabular}

This table provides the logistics regression analysis results of the effect of managerial ability on subsequent stock price crash risk. ${ }^{*}, * *$ and ${ }^{* * *}$ denote significance at the $10 \%, 5 \%$, and $1 \%$ levels, respectively. Refer to Table 2 for the variable definitions. 
Table 5 Column (3) shows how large business group firms impact the effect of managerial ability in weakening stock price crash risk. To examine the effects of large business group firms on the relationship between managerial ability and stock crash risk, we included $C O N G L O_{t}$ and $\left(M A_{t}^{*} \mathrm{CONGLO} \mathrm{O}_{t}\right)$ as interaction terms, i.e., interest variables of Hypothesis 2. Interaction terms, $M A_{t}{ }^{*} \mathrm{CONGLO} \mathrm{O}_{t}$ variables had a significant positive coefficient, implying that the negative association between managerial ability and future stock price crash risk weakens. In the case of firms in large business group, the owners have a long-term investor's perspective rather than emphasize short-term profit; hence they rely less on timely disclosure information. In addition, because of their direct involvement in corporate management and their accessibility to corporate information, the demand for corporate information to monitor the management may decrease as a result [38]. Therefore, this increases the subsequent stock price crash risk by increasing the accumulation of bad news inside the company.

To perform a robustness check, we did a separate regression analysis by large business group firms (CONGLO) and the others (NON-CONGLO). The first column of Table 6 is the logistic regression result of firms in large business group. The coefficient of $M A_{t}$ has a significant and positive value. This suggests that managers with high ability tend to increase future stock price crash risk in the case of firms in large business group. However, in the second column of Table 6 which is the regression result of firms not belonging to large business group, the coefficient of $M A_{t}$ has a significant and negative value. Thus, we found a significant evidence that managers with high ability tend to decrease future stock price crash risk in the case of non-large business group firms. These results are similar to the results from the full sample. Taken together, the overall results in Table 6 implies that the negative relation between managerial ability and future stock price crash risk is weaker when the firms belong to large business group, which is supported by the results in Table 5.

Table 6. Subsample test of the effect of managerial ability on stock price crash risk.

\begin{tabular}{|c|c|c|}
\hline \multirow{2}{*}{ Variables } & \multicolumn{2}{|c|}{$\mathrm{CRASH}_{t+1}$} \\
\hline & CONGLO & NON-CONGLO \\
\hline Intercept & $\begin{array}{c}1.008 \\
(0.777)\end{array}$ & $\begin{array}{l}-0.571 \\
(0.765)\end{array}$ \\
\hline$M A_{t}$ & $\begin{array}{l}2.543 \text { ** } \\
(0.040)\end{array}$ & $\begin{array}{c}-2.004^{* * *} \\
(0.002)\end{array}$ \\
\hline$S I Z E_{t}$ & $\begin{array}{l}-0.127 \\
(0.320)\end{array}$ & $\begin{array}{l}-0.044 \\
(0.536)\end{array}$ \\
\hline$M B_{t}$ & $\begin{array}{l}0.205^{*} \\
(0.072)\end{array}$ & $\begin{array}{l}-0.032 \\
(0.671)\end{array}$ \\
\hline TRADING $_{t}$ & $\begin{array}{l}1.226^{* *} \\
(0.036)\end{array}$ & $\begin{array}{c}0.082 \\
(0.508)\end{array}$ \\
\hline STDRET $_{t}$ & $\begin{array}{l}-0.957 \\
(0.914)\end{array}$ & $\begin{array}{l}-2.760 \\
(0.386)\end{array}$ \\
\hline$M N R E T_{t}$ & $\begin{array}{l}-6.620 \\
(0.703)\end{array}$ & $\begin{array}{c}17.063 * * \\
(0.040)\end{array}$ \\
\hline$L E V_{t}$ & $\begin{array}{c}1.065 \\
(0.132)\end{array}$ & $\begin{array}{c}0.343 \\
(0.295)\end{array}$ \\
\hline$B E T A_{t}$ & $\begin{array}{c}0.412 \\
(0.295) \\
\end{array}$ & $\begin{array}{l}-0.208 \\
(0.279) \\
\end{array}$ \\
\hline$R O A_{t}$ & $\begin{array}{l}-5.156^{* *} \\
(0.013)\end{array}$ & $\begin{array}{c}-3.849^{* * *} \\
(0.000)\end{array}$ \\
\hline $\mathrm{OPAQUE}_{t}$ & $\begin{array}{c}0.136 \\
(0.374)\end{array}$ & $\begin{array}{l}-0.011 \\
(0.924)\end{array}$ \\
\hline TENURE $_{t}$ & $\begin{array}{c}-0.090^{* *} \\
(0.015)\end{array}$ & $\begin{array}{c}0.019 \\
(0.181)\end{array}$ \\
\hline $\mathrm{CRASH}_{t}$ & $\begin{array}{l}-0.427 \\
(0.211) \\
\end{array}$ & $\begin{array}{c}0.092 \\
(0.572) \\
\end{array}$ \\
\hline Industry dummies & \multicolumn{2}{|c|}{ Included } \\
\hline Year dummies & \multicolumn{2}{|c|}{ Included } \\
\hline Observations & 962 & 2982 \\
\hline
\end{tabular}

This table shows subsample test results regarding the relation between managerial ability and stock price crash risk. $*{ }^{* *}$ and ${ }^{* * *}$ denote significance at the $10 \%, 5 \%$, and $1 \%$ levels, respectively. Refer to Table 2 for the variable definitions. 


\section{Discussion and Conclusions}

This study explored how managerial ability influences future stock price risk using Korean listed firms' observations. Using the DEA method suggested by [14] to measure managerial ability and market-based measure for subsequent stock price crash risk which was also used by [7], we examined the relationship between managerial ability and stock price crash risk by conducting empirical analysis. Compared to some financially advanced countries, managers tend to exert more powerful influence on the firm in Korea, as ownership and management are not effectively separated in most Korean firms. In addition, we considered the effect of large business groups called Chaebol, which is family-run conglomerates with unique corporate governance system and hugely affect the Korean economy. If managers with higher ability release more voluntary disclosures to signal their ability, we would expect managerial ability to be associated with lower stock price crash risk. On the other hand, if managers with higher ability are less likely to issue disclosures for opportunistic reasons and thus hoard bad news, managerial ability could be correlated with higher future crash risk. Furthermore, the relationship between managerial ability and subsequent stock price crash risk would be affected by the role of large business group firms.

Utilizing 3944 observations of KOSPI listed firms over the period from 2002 to 2014, we found that there is a significantly negative relation between managerial ability and subsequent stock price crash risk. We interpret this result as meaning that managers with higher ability have more incentives to disclose information to signal their ability, resulting in lower future stock price crash risk. Furthermore, we find that firms in large business group significantly weakens the negative relationship between managerial ability and subsequent stock price crash risk. This may imply that the demand for corporate information in large business group firms may be reduced because they already have high access to such information thanks to owner's direct involvement in management, and bad news hoarding would increase as a result. Hence, firms belong to large business group play a role of weakening the positive effect of managerial ability on the subsequent stock price crash risk.

Our study contributes to the growing literature on the subject of stock rice crash risk and managerial ability and their implications on firms and investors. In this study, we pay attention to the unique role of managerial ability as one of the factors of stock price crash risk and provide the evidence of the effect of large business group, i.e., Chaebol, on the association between managerial ability and stock price crash risk. We also use more sophisticated methods to measure managerial ability in identifying a new factor of subsequent stock price crash risk.

Author Contributions: Soo Yeon Park and Hoon Jung conceived and designed the researches; Soo Yeon Park and Hoon Jung analyzed the data; Soo Yeon Park and Hoon Jung wrote the paper. Soo Yeon Park and Hoon Jung contributed equally in this paper.

Conflicts of Interest: The authors declare no conflict of interest.

\section{References}

1. Hambrick, D.; Mason, P. Upper echelons: The organization as a reflection of its top managers. Acad. Manag. Rev. 1984, 9, 193-206. [CrossRef]

2. Bertrand, M.; Schoar, A. Managing with style: The effect of managers on firm policies. Q. J. Econ. 2003, 118, 1169-1208. [CrossRef]

3. Bamber, L.S.; Jiang, J.; Wang, I.Y. What's my style? The influence of top managers on voluntary corporate financial disclosure. Account. Rev. 2010, 85, 1131-1162. [CrossRef]

4. Graham, J.R.; Harvey, C.R.; Rajgopal, S. The economic implications of corporate financial reporting. J. Account. Econ. 2005, 40, 3-73. [CrossRef]

5. Hambrick, D.C. Upper echelons theory: An update. Acad. Manag. Rev. 2007, 32, 334-343. [CrossRef]

6. Huang, S.K. The impact of CEO characteristics on corporate sustainable development. Corp. Soc. Responsib. Environ. Manag. 2013, 20, 234-244. [CrossRef]

7. Hutton, A.P.; Marcus, A.J.; Tehranian, H. Opaque financial reports, $\mathrm{R}^{2}$, and crash risk. J. Financ. Econ. 2009, 94, 67-86. [CrossRef] 
8. Kim, J.; Li, Y.; Zhang, L. CFOs versus CEOs: Equity incentives and crashes. J. Financ. Econ. 2011, 101, 713-730. [CrossRef]

9. Kim, J.; Li, Y.; Zhang, L. Corporate tax avoidance and stock price crash risk: Firm-level analysis. J. Financ. Econ. 2011, 100, 639-662. [CrossRef]

10. Hamm, S.J.W.; Li, E.X.; Ng, J. Management Earnings Guidance and Stock Price Crash Risk. Available online: https: / / doi.org/10.2139/ssrn.2055008 (accessed on 12 December 2017).

11. Kothari, S.P.; Shu, S.; Wysocki, P.D. Do managers withhold bad news? J. Account. Res. 2009, 47, $241-276$. [CrossRef]

12. Jin, L.; Myers, S.C. R 2 around the world: New theory and new tests. J. Financ. Econ. 2006, 79, $257-292$. [CrossRef]

13. Jensen, M.C.; Meckling, W.H. Theory of the firm: Managerial behavior, agency costs and ownership structure. J. Financ. Econ. 1976, 3, 305-360. [CrossRef]

14. Demerjian, P.; Lev, B.; McVay, S. Quantifying managerial ability: A new measure and validity tests. Manag. Sci. 2012, 58, 1229-1248. [CrossRef]

15. Trueman, B. Why do managers voluntarily release earnings forecasts? J. Account. Econ. 1986, 8, 53-71. [CrossRef]

16. Baik, B.; Farber, D.B.; Lee, S.S. CEO ability and management earnings forecasts. Contemp. Account. Res. 2011, 28, 1645-1668. [CrossRef]

17. Francis, J.; Huang, A.H.; Rajgopal, S.; Zang, A.Y. CEO reputation and earnings quality. Contemp. Account. Res. 2008, 25, 109-147. [CrossRef]

18. Malmendier, U.; Tate, G. Superstar CEOs. Q. J. Econ. 2009, 124, 1593-1638. [CrossRef]

19. Kim, J.; Zhang, L. Accounting conservatism and stock price crash risk: Firm level evidence. Contemp. Account. Res. 2016, 33, 412-441. [CrossRef]

20. Kim, J.; Wang, Z.; Zhang, L. CEO overconfidence and stock price crash risk. Contemp. Account. Res. 2016, 33, 1720-1749. [CrossRef]

21. Callen, J.L.; Fang, X. Institutional investor stability and crash risk: Monitoring versus short-termism? J. Bank. Financ. 2013, 37, 3047-3063. [CrossRef]

22. Xu, N.; Jiang, X.; Chan, K.C.; Yi, Z. Analyst coverage, optimism, and stock price crash risk: Evidence from China. Pac. Basin Financ. J. 2013, 25, 217-239. [CrossRef]

23. Jo, E.; Moon, H.; Choi, Y. The effect of comparability on firm-level stock price crash risk. Korean Account. Rev. 2015, 40, 179-211.

24. Song, L. Accounting disclosure, stock price synchronicity and stock crash risk: An emerging-market perspective. Int. J. Account. Inf. Manag. 2015, 23, 349-363. [CrossRef]

25. Andreou, P.C.; Louca, C.; Petrou, A.P. CEO age and stock price crash risk. Rev. Financ. 2016, 21, 1287-1325. [CrossRef]

26. Fee, C.E.; Hadlock, C.J. Raids, rewards, and reputations in the market for managerial talent. Rev. Financ. Stud. 2003, 16, 1315-1357. [CrossRef]

27. Gabaix, X.; Landier, A. Why has CEO pay increased so much? Q. J. Econ. 2008, 123, 49-100. [CrossRef]

28. Demerjian, P.R.; Lewis-Western, M.; Lev, B.; McVay, S.E. Managerial ability and earnings quality. Account. Rev. 2013, 88, 463-498. [CrossRef]

29. Park, J.; Ko, C.Y.; Jung, H.; Lee, Y. Managerial ability and tax avoidance: Evidence from Korea. Asia-Pac. J. Account. Econ. 2016, 23, 449-477. [CrossRef]

30. La Porta, R.; Lopez-de-Silanes, F.; Shleifer, A. Corporate ownership around the world. J. Financ. 1999, 54, 471-517. [CrossRef]

31. Kim, J.; Yi, C.H. Ownership structure, business group affiliation, listing status, and earnings management: Evidence from Korea. Contemp. Account. Res. 2006, 23, 427-464. [CrossRef]

32. Choi, M.H. The moderating effect of corporate governance on the relations between corporate social responsibility and cost of capital. Korea Int. Account. Rev. 2013, 51, 335-356.

33. Khanna, T.; Palepu, K. Is group affiliation profitable in emerging markets? An analysis of diversified Indian business groups. J. Financ. 2000, 55, 867-891. [CrossRef]

34. Shim, S.G.; Kim, C.S. The effect of executive stock options compensation on accounting conservatism. Account. Inf. Rev. 2010, 28, 215-244. 
35. Chen, S.; Chen, X.; Cheng, Q. Do family firms provide more or less voluntary disclosure? J. Account. Res. 2008, 46, 499-536. [CrossRef]

36. Anderson, R.C.; Reeb, D.M. Founding-Family Ownership and Firm Performance: Evidence from the S\&P 500. J. Financ. 2003, 58, 1301-1328.

37. Bushman, R.M.; Piotroski, J.D.; Smith, A.J. What determines corporate transparency? J. Account. Res. 2004, 42, 207-252. [CrossRef]

38. Lee, A.Y.; Kim, S.H.; Kang, Y.S. The Firms in Large Business Group and the Voluntary Disclosure. Korean J. Account. Res. 2012, 17, 57-81. [CrossRef]

39. Grossman, S.J.; Hart, O.D. Takeover bids, the free-rider problem, and the theory of the corporation. Bell J. Econ. 1980, 11, 42-64. [CrossRef]

40. Milgrom, P.R. Rational expectations, information acquisition, and competitive bidding. Econometrica 1981, 49, 921-943. [CrossRef]

41. Verrecchia, R.E. Discretionary disclosure. J. Account. Econ. 1983, 5, 179-194. [CrossRef]

42. Verrecchia, R.E. Essays on Disclosure. J. Account. Econ. 2001, 32, 97-180. [CrossRef]

43. Kasznik, R.; Lev, B. To warn or not to warn: Management disclosures in the face of an earnings surprise. Account. Rev. 1995, 70, 113-134.

44. Aboody, D.; Kasznik, R. CEO Stock Option Awards and the Timing of Corporate Voluntary Disclosures. J. Account. Econ. 2000, 29, 73-100. [CrossRef]

45. Ko, C.Y.; Park, J.H.; Jung, H.; Yoo, K.H. A Study on the Effects of Managerial Ability by DEA on Firm Performance. Korean J. Manag. Account. Res. 2013, 13, 165-200.

46. Harvey, C.R.; Siddique, A. Conditional skewness in asset pricing tests. J. Financ. 2000, 55, 1263-1295. [CrossRef]

47. Simsek, Z. CEO tenure and organizational performance: An intervening model. Strateg. Manag. J. 2007, 28, 653-662. [CrossRef]

48. Ko, C.Y.; Jung, H. The Effect of Managerial Ability on Executive Compensation. J. Financ. Account. Inf. 2016, 16, 113-139.

49. Chen, J.; Hong, H.; Stein, J.C. Forecasting crashes: Trading volume, past returns, and conditional skewness in stock prices. J. Financ. Econ. 2001, 61, 345-381. [CrossRef]

50. Callen, J.L.; Fang, X. Short interest and stock price crash risk. J. Bank. Financ. 2015, 60, 181-194. [CrossRef] 